\title{
Universities, Governments, and the Public ${ }^{*}$
}

\author{
H. IAN MACDONALD**
}

Having spent ten years in academic life and then ten years in government, I am intrigued by some of the inherent differences that have emerged in the course of my experience. As an academic in the Department of Economics at the University of Toronto, interested in matters of public policy, $I$ found that $I$ had the freedom to speak but not the access to the facts; then, as a civil servant, $I$ had the access to the facts but not the freedom to speak. I have often thought that, if we could find some way to wed those two separate states, public policy would certainly be the beneficiary.

Over the past few months, I have been meeting informally with the faculty members of York University to seek their opinions and advice on the problems and future directions of the University. Throughout those discussions, I found two prevailing themes occurring over and over again. The first is that we must begin immediately to determine our objectives and to chart our future course, thereby being in a position to respond positively, coherently and strongly to the various criticisms that are being levelled against us. The second is related to the first, and that is the festering tension and misunderstanding that has emerged over the past few years between the academic community and government. Circumstances such as modest enrolment increases, increased government scrutiny of the details of university operations, and a certain uneasiness in the public's mind have resulted in a widening of the gap. It is now imperative to find ways of narrowing it. A situation of two solitudes has emerged and created an unhealthy state of affairs.

The present relationship between government and the universities must be seen against the rapid growth of universities in the sixties and the sudden change of direction and the emergent priorities of government in the seventies. I do not think that the seventies are all that different from earlier periods, except in one particular - they succeeded the sixties! The sixties, in a sense, are the anomaly in the history of universities, in that universities have always had a particularly difficult cross to bear before the public, in withstanding accusations of elitism and in making their particular values and responsibilities known. Universities are not the institution most readily understood or even appreciated by the man on the street, but in the sixties they went through a period of virtual euphoria in terms of expansion and, perhaps, came to believe that such a condition would endure forever. Thus, the contrast of the seventies is the sharper

*This article is based on an address given by President Macdonald to the Association of Canadian University Information Bureaus on September 29, 1975 in Halifax.

**President, York University. 
and the occurrence in the seventies of escalating inflation, which has imposed so heavily on all universities, has added a special dimension to their difficulties.

During the sixties post-secondary institutions in Canada developed at an unprecedented rate. In a relatively short space of years, the number of provincially supported universities in Ontario grew from 7 to 15, and 22 new Colleges of Applied Arts and Technology were created as part of the post-secondary system. In fact, I recall, when I was Chief Economist in the Ontario Government, calculating that post-secondary capital investment in the quinquennial period 1967-1972 in Ontario would surpass all of that which had taken place in the previous 100 years of Confederation.

That was the era of "the quantitative revolution" in education. There were some persons, even in those days, who expressed concern from time to time about the extent of the outlay and the pace of events, but our social, economic, and demographic circumstances were such that we really had no choice. But I think there was a fundamental mistake made in those days, and I do not make that comment with the virtue of hindsight, because I remember my rather passionate debates with educators about what I thought was a mistaken application of a piece of economic jargon to justify expenditure in education, that unfelicitous phrase "investment in human capital."

Throughout the sixties not only educators, but indeed the Economic Council of Canada, tried to suggest that the ultimate justification of expenditure in education was an investment in human capital from which we would get an ever-expanding gross national product. The economic justification was of the same character as investing in a factory or, for that matter, in a super highway. I remember arguing rather forcefully against that proposition because, first of all, I believe that education is more than an economic process, more than a means to an end, and more than mere occupational training. It is a prerequisite of a civilized society and a process whose intrinstic worth has been demonstrated over and over again. I believe the true justification of higher education is to be found in terms of social and cultural development, the broadened horizons of individuals, and the extension of the frontiers of knowledge, particularly in Canada, which is changing so rapidly as a result of newcomers becoming a part of this country. It also seemed to me that, if the great hopes for high economic returns to education were unfulfilled, then there would be a very strong reaction against expenditure on education. In a sense, the failure to fulfill the too high hopes, in economic terms, which were placed on education in the sixties is something we are experiencing today, as part of the public backlash, or at least part of the public questioning, about the value of higher education.

In the 1970's universities are undergoing "the qualitative revolution" in which more and more pointed questions are asked about the quality of life rather than the quantity of life. In this atmosphere, there are great opportunities for universities to say something of intrinsic worth to society. I do not agree with those professional purveyors of gloom who talk about universities as "a declining industry," - one that is doomed to financial failure and intellectual impotence. That will happen only to the extent that those responsible for university affairs let it happen, because universities are needed more than ever before. In his Installation Address, Principal Watts of Queen's University demonstrated very well that on the one hand we have a huge list of objectives in terms of social improvement and betterment of life and on the other hand universities are unique- 
ly well-equipped to contribute to the fulfillment of those goals. Surely it is paradoxical that, at this very time, universities are under increasing financial stress, and unable to afford the kind of quality which we all believe that universities require and deserve. The question then is not: "Do we need universities?" It is: "What should universities be in the modern world?"

Meanwhile, what kind of framework do universities face in the government world? In the first place, as long as the constitutional responsibilities of Canadian Confederation remain intact and the revenue sources among the three levels of government remain unreformed, it is inevitable that education and a variety of other socially desirable activities will face financial hardship. I frankly see no relaxation in that condition throughout this decade and certainly the discussions that have taken place in Ontario - the presidents of universities and their board chairmen with the Premier, with the Minister of Colleges and Universities, and with Ministry officials - suggest that the financial outlook for universities may not get any worse, but it probably will not get much better, unless ways are found to change that outlook and change the universities' place in public priorities.

What is the basis of this austere forecast? In recent years the provincial governments have been faced with massive deficits and cash requirements far in excess relatively of those of the federal government. Most provincial governments are also committed to major transfers to the municipal level of government to offset its sole dependence on the regressive property tax. In addition, the current concern about quality of life means that massive new demands are arising within the constitutional umbrella of provincial governments. Environmental protection and enhancement, mass urban transit, preservation of agriculture land, beautification of cities, development of recreation and open space, urban renewal, and public housing are all pressing their claims. One of the last decisions in which I was involved in my own Ministry before leaving the Government was the decision to embark upon the protection of some 1.3 million acres of the Niagara Escarpment and to provide a parkway belt from Hamilton to Oshawa around Metropolitan Toronto involving an outlay of at least 1 billion dollars over the next few years, with more to come. It seems to me that, in the face of these demands, education, health and the traditional social services will face exceedingly strong competition for funds.

In addition, Canadian society is at a critical turning point in terms of the whole economic process which is not really understood in terms of public policy. This is not a criticism of any government or individual. But the Western economic system is experiencing a basic and fundamental change that has not really entered into public debates or discussions. In terms of the old demand and supply factors of economics, the economic system is gradually moving into the so-called "steady state" on the supply side. Productivity is not increasing, economic growth has ceased, the concern about conservation and about the quality of life, and the questioning about ceaseless economic growth of goods and services is having a profound effect on the output side, but the demand for goods and services is still based on acquisitiveness and expectations of an increased standard of living. The simple consequence is endemic inflation. This situation is obviously imposing heavily on universities. In the case of York University for example, revenue will increase this year by 11.6 per cent, salaries by 13 per cent, our other basic 
costs of services by 15 percent. Obviously, there is an unbridged gap!

The question now at hand is: "Can the need and desire to re-establish the position of the university on the ladder of public priorities be reconciled with the evident shift in government policy and public attitudes away from the university?" It can be, but first certain essential ingredients in the thinking of universities are required. First of all, the necessity of reaching clear agreement on priorities, goals, and objectives must be recognized and accepted. A fundamental look must be taken at what things each university does best and where it is going. Perhaps it is easier to say this as the President of an institution that is 16 years old and still maturing, compared with the situation that often obtains in older universities. But it does pose a fundamental question of educational philosophy. What does it take to continue to be a university and to warrant the name of a university? One could presume, for example, that a Faculty of Medicine or a Faculty of Engineering is not necessary for an institution to be a university. If that is not true, then York is not a university. Could an institution be a university without having a Department of Philosophy or a Department of English, or of French Literature in this country?

The question of how resources should be distributed through the university system in the direction of greater concentration on strengths, greater complementarity and means for avoiding wasteful competition - if there is wasteful competition - is something that will demand careful and analytic consideration. We have not progressed beyond the broad generalizations which are not very helpful. For example, officials in ministries and governments say to universities that there is a lot of duplication in the university system. This proposition is not very useful unless the universities pick up that challenge and ask: "Is there duplication, and if so, is it genuine or healthy duplication of activities or courses?" Universities must answer that question for themselves as individual institutions, and collectively as a university system.

Secondly, the university must develop a greater appreciation of the issues and problems facing governments in their efforts to determine priorities. Having lived on each side of the fence, I believe there is an unhealthy tension, for example, between the Ministry of Colleges and Universities in Ontario and the province's universities. I say "unhealthy" because there is not sufficient openness, too much suspicion about motives, and an apparent unwillingness to work together for the betterment of the universities. Much more openness is needed between the universities on the one hand, and the government on the other. Much more mobility of people back and forth between the universities and goverriment is also necessary. The adversary relationship now existing between universities and government should be replaced with a cooperative one. Finally, universities need to learn how to lobby and how to approach governments.

Universities must prepare themselves to press their case more positively and more aggressively in the public arena. Marches on the legislature - an increasing social phenomenon which has become one of increasing tedium for the ministers and officials involved - are not the course of action implied here (at the time I was leaving government service, there was serious discussion about setting up a booking agency for demonstrations because they were sometimes getting in one another's way and reducing the effectiveness of the process). The groups that universities should address are the public, the press, and the media of mass communication. 
Canadians are in danger of diminishing the basic quality of their universities as a result of under-financing, but it is not sufficient to blame an uncomprehending public or an unsympathetic government. Rather, like a boxer who has over-extended himself in the ring, universities are on the ropes and are reacting to every additional body blow they receive. When a new financial formula rolls out, or when a newspaper tells universities that they can quadruple the number of people in the classrooms without impairing the quality of education, or they must tighten admission standards, they reel and react by going on the defensive.

Until the universities recover the initiative and make a positive attack on these questions, they are not going to convince the public or themselves that they should move up the priority ladder. For example, there is a very great danger today that another misapplied piece of economic jargon is being applied to higher education, and that is the term "productivity." Universities are being told by governments and editorial writers that they must increase their productivity. When one asks what increased productivity means in those terms, the answers are that the number of students in the classroom can be doubled or quadrupled, the teaching load can be increased and that the staff/ student ratio can be changed. Surely this is merely an arithmetic axiom. It tells nothing at all about the quality of education. We must deal not with productivity, but with productiveness and effectiveness. We have all had experiences suggesting that there are wide variations in the process. If good teaching is defined as the challenge to preconceived dogma, or the arousal of intellectual curiosity, or the broadening of the horizons of the mind, some of the best teaching $I$ had as an undergraduate at the University of Toronto was in a class of 200 . I am sorry to confess that some of the worst teaching I had was in a one-to-one ratio at the University of Oxford. The main problems about the use of productivity are that it is based on a narrow definition of the role of the university, and may lead to either a reaction or compliance which ultimately is not in the best interests of the university.

There are those who attack on the ground of the under-utilization of universities or of teaching but at the same time say that the universities are too large, too anonymous and not paying enough attention to the individual students. These persons would have it both ways. And indeed just using the ratios ignores the whole process of the extraclassroom responsibilities of faculty members for supervision and so on. It certainly ignores the other fundamental responsibilities of the university in terms of scholarship, research, and public service. It involves a dangerous, narrowing tendency for the public perception of the university.

In the same manner, universities are being told - or it is being suggested to them - that they should reduce enrolments and tighten admission standards. There are varying views among university presidents on this question, depending largely on whether or not their institutions have matured in the sense of having reached optimum size or desired goals. But the proposition that, by some arithmetic yardstick, one might arbitrarily reduce opportunities for admission to university or change admission standards is disconcerting because all of the problems of equality of educational opportunity in this country have not been solved. For example, I am not convinced that we have achieved equality of opportunity among potential university entrants, particularly people who have language handicaps but are otherwise well-equipped to do university 
work. I am not convinced that all of those things that can be done through the school system have been done to ensure that those in a position to benefit from and contribute to university are getting there.

Moreover, it is impossible to answer the question what should university enrolment be and what should admission standards be, until the role and function for the universities in Canada are defined. What are these roles and functions in terms of the choice between continuing with mass education or returning to a more restrictive academy? What are they in terms of the choice between greater emphasis on general education as opposed to occupational preparation? What are they in terms of increasing the inflow of students from the final year of high school as opposed to increasing the number of persons who return to university life continuously or at advanced stages of maturity? Until universities are able to answer some of these questions more effectively, it will be very difficult to deal with the "means" question. More important, until universities answer some of these questions they will continue to reel on the ropes under the public onslaught.

The people of this country are not anti-education. The basic belief in the importance of education is as strong and as fundamental as ever. But there are basic questions about whether or not universities clearly know where they should go, what their goals and objectives are, and how they should best get there.

In 1956, Canadian universities faced a problem different from that which they face today. The problem then was that a virtual tidal wave of postwar babies would arrive at the universities' doors in the late 1950's and 1960's and that there would be a need to adapt the university system quickly to deal with those numbers. The National Conference of Canadian Universities held a national meeting in Ottawa in 1956 on "the crisis in higher education." It is interesting to read the proceedings of this Conference, because it did have a significant effect on the direction of public policy in Canada. It is evident from a review of the recommendations and discussions of that Conference, and from subsequent occurrences that the universities did seize the initiative and did chart a course for themselves that has served them and the country well.

Another national conference on the future of Canadian universities should be convened before the end of 1976 . Such a conference would be a first step towards answering the questions about the roles and functions of universities in Canadian society over the next ten years.

A national conference will not solve all of the universities' problems. But we should return to some of the basic questions about fundamental philosophy of the university system and university education, which have been ignored recently. A national conference would enable universities to recapture the initiative and then assume a stronger position from which to convince the public and governments that once again universities merit their continuing and indeed increasing support.

In every decision which bears on the broad policy of the university a question should be asked about whether or not the university system is destined to have more government interference in its operation. Although one should have no illusions that, in a publicly funded university system, governments have no role in the system, it is nevertheless fundamentally important for universities to retain and enhance in every possible way whatever degree of self-determination or autonomy is available to them. In most 
decisions taken about universities, one should ask whether or not these decisions are going to contribute to this end. Questions about autonomy lead to other questions. These are two especially important examples. How long can universities go on incurring deficits? There is a point of view held by some persons which contends that the university should not worry about this, but should go on incurring deficits because eventually the government will bail them out. It is inconceivable, that if all the universities in Ontario, for example, were to incur increasingly large deficits, at some point the Government would not feel obliged to introduce some form of trustee arrangement, and play a direct role in the academic decision-making of the university.

The second question has to do with the prospect of faculty unionization, which is on the horizon and, in some instances, closer than on the horizon. Collective bargaining and unionization is a hard-earned right in Canadian society and, indeed, is a basic right of any group of people. Faculties themselves must decide on this question. But it is imperative that there be every opportunity for the faculty to debate the issue, to understand the implications, and to consider the potential advantages and disadvantages and the ultimate results. This can become a complicated and painful procedure.

At York University, support staff have recently had a bargaining unit determined for them under the Ontario Labour Relations Act. When one tries to apply a statute that was born in the copper mines and on the assembly lines to a culture such as that in the university, which has a highly decentralized form of management, the institution experiences cultural shock. Similarly, there is a passage in the Ontario Labour Relations Act which says that any employee who has any influence over the salary, promotion, discharge or other terms of employment of a fellow employee is part of management and is not eligible for the union. Faculties should consider very carefully and take all available advice about the potential implications of unionization for the whole collegial process of peer evaluation, promotion, and tenure, under which universities have lived for 700 years.

In all that has been said here, nothing has been said about the Canadian federal government: this is one of the difficult questions of public policy. We all understand two things: ultimately universities are a national resource and, therefore, the federal government should bear some public responsibility for their welfare. We all also understand our constitution and the ultimate responsibilities of the provincial governments. The federal government must be persuaded to do more and to take a larger role. The Fiscal Arrangements Act, whereby the federal financial resources for the purposes of higher education are transferred through the tax mechanism to the provincial treasuries, will shortly come up for review. These discussions should not be just arithmetic exercises about the size of the funds and manner of handling them. The universities should have a strong positive position on their educational needs to place before the federal government and the provinces. Twenty years ago, universities were in a position to speak with a direct voice to the ministers and to the political men and women who ultimately were responsible for decisions about higher education. Since then strong and powerful bureaucracies dealing with university and educational matters have been built up in both the provincial and federal governments. It is not only strong university presidents or influential faculty groups who make their presence known to politicians, but there also are very strong counter-bureaucracies, as it were, that are also advising governments and with 
which universities must deal and reckon. These large bureaucracies often have resources which the universities simply cannot muster.

A story is told about a former student who came to visit his old Professor of Economics after fifteen years and happened to notice a copy of the current examination paper lying on the desk. He glanced over it and said to the professor: "You know that is very interesting. If I recall, those are exactly the same questions you asked us in our examination fifteen years ago." The professor said, "Oh yes, I ask the same questions every year," and the former student asked, "Well, don't your students get wise to the system?" to which he replied, "Of course, but it does not matter because in Economics we keep changing the answers!"

Both the questions and the answers are now changing very rapidly in matters of public policy and in the area of the relationship of universities and government. It is critically important that the universities retain a capacity to play a part in the asking of the questions and in providing of the answers. There is a very great danger, in a mood of retrenchment, in a concern and anxiety about the future, and in a stance of reacting to body blows rather than taking the initiative, that three forces may overcome universities at once - the force of collectivism, the force of conservatism, and the force of protectionism. Universities should prepare themselves to counter them all. 